Contacts

Publisher: Fabien Savenay

Editor: Paul Smaglik

Sales Director: Ben Crowe

European Head Office

London

The Macmillan Building

4 Crinan Street

London N1 9XW, UK

Tel +44 (0) 2078434961

Fax +44 (0) 2078434996

e-mail: naturejobs@nature.com

Senior European Sales Manager: Nevin Bayoumi (4978)

UK/ RoW/ Ireland:

Matt Powell (4953)

Andy Douglas (4975)

Laura Pearson (4977)

Netherlands/ Italy/ Iberia:

Evelina Rubio Hakansson (4973)

Scandinavia: Sille Opstrup (4994)

Production Manager: Billie Franklin

To send materials use London

address above.

Tel +44 (0) 2078434814

Fax +44 (0) 2078434996

e-mail: naturejobs@nature.com

International

Advertising Coordinator

Hind Berrada (4935)

Naturejobs web development

Tom Hancock

Naturejobs online production

Ben Lund

European Satellite Offices

France/ Belgium:

Christine Niox-Chateau

Tel +33 (0) 143201651

Fax +33 (0) 143205152

e-mail. cnioxchateau@nature com.

Germany/ Austria/ Switzerland:

Patrick Phelan

Tel + $498954905711 /-2$

$\mathrm{Fax}+498954905720$

e-mail: p.phelan@nature.com

US Head Office, New York

345 Park Avenue South,

10th Floor, New York, NY 10010-1707

Tel +1 8009897718

$\mathrm{Fax}+18009897103$

e-mail: naturejobs@natureny.com

US Sales Director: Ben Crowe US Sales Manager: Peyton Mason

US Advertising Coordinator:

Ashly de Leon

Japan Head Office, Tokyo

MG Ichigaya Building (5F),

19-1 Haraikatamachi,

Shinjuku-ku,

Tokyo $162-0841$

Tel +81332678751

Fax +81332678746

e-mail:k.johnson@naturejpn.com

Asia-Pacific Advertising Manager:

Kewn Johnson

\title{
naturejobs
}

\section{Landing the egos}

$\mathrm{n}$ helping to start three biotech companies in the Seattle area (see pages 4-5), Chris Henney has had to be a good judge of scientific talent. But he calls himself "a pretty bad interviewer". So how has he managed to recruit scientists for Immunex -

which is in the process of being acquired by Amgen of Thousand Oaks, California - Icos, which hopes to market its first drug in a year; and Dendrion, which is still developing? "I usually just say: 'Tell me what you've been doing,' he says.

This open-ended question usually reveals more than people intend. "I look for high-energy, open-minded people," Henney says. What does he want to avoid? "Guys who want to spend their life repeating their $\mathrm{PhD}$ thesis," he says. Shaking his head, he adds in his staccato mantra: "It's probably not going to work."

The other thing he watches for - both in interviews and once a new recruit has started - is ego. "We all have well-developed egos in the biotech world," Henney says. But he emphasizes that a little goes a long way, and that the line between confidence and arrogance can be relatively blurred.

So what are some ego-related disqualifiers? People who worry about other people going into their office. "It's probably not going to work," says Henney. People who want their own private parking space. "It's not gonna work," says Henney. A desk with a name embossed in metal or some exotic polymer. "Not gonna work," he says.

The best kind of confidence, according to Henney, is the kind that has to do with honest intellectual pursuit, rather than the trappings of success or status. "You're looking for people who don't have to win every argument," Henney says. That qualification is desirable in any scientific setting, academic or industrial.

\section{Paul Smaglik}

Naturejobs editor
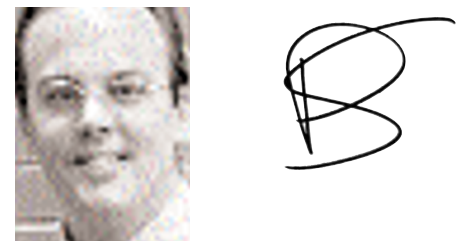

SPOTLIGHT

RECRUITMENT

SCIENTIFIC ANNOUNCEMENTS
Career centre

Information on the scientific job market 